ФІНАНСИ. БАНКІВСЬКА СПРАВА

УДК 336.71

Т. П. Гончаренко, к. е. н.

\section{ОСОБЛИВОСТІ ВИЗНАЧЕННЯ} БІЗНЕС-СТРАТЕГІЙ БАНКІВ В УКРАÏНІ

Актуальність теми дослідження полягає в необхідності розширення існуючих методичних засад визначення бізнес-стратегій з метою розвитку ринку банківських послуг в Україні.

Постановка проблеми. 3 метою активізації фрінансово-економічних процесів в Україні необхідно сорормувати грунтовний інформаційний базис прийняття ефективних управлінський рішень в сфрері банківського менеджменту.

Аналіз останніх досліджень і публікацій. У науковій та фраховій літературі питанням дослідження бізнесстратегій банків присвячено увага таких вчених, як Гриджук Д. М., Деркаченко А. В., Худолій Ю. С., Заруцька О. П., Пантєлєєва Н. М., Рашкован В. та інші.

Виділення недосліджених частин загальної проблеми. Не применшуючи значення отриманих наукових результатів слід відмітити, що на сьогоднішній день недостатньо розвинуті методичні засади визначення бізнес-стратегій банків в Україні.

Постановка завдання. розробка науковометодичного підходу до ідентифрікації бізнес-стратегій банків в Україні.

Виклад основного матеріалу. Зважаючи на загальну практику діяльності банків, обрання показників характеристики їх бізнес-стратегій повинні сорормувати два напрямки: джерела фрормування банківських ресурсів та напрямок фрінансування (кредитування). Математичний інструментарій ідентифікації бізнес стратегій банків виступає: дівізівний метод k-середніх в розрізі множини багатомірних дослідницьких методів та дисперсійний аналіз.

Висновки. Визначення бізнес-стратегій банків в Україні дозволить як його учасникам, так $і$ державним органам регулювання сорормувати в майбутньому найбільш ефективне ринкове середовище. Це дозволить інтенсифрікувати не тільки процеси розвитку банківського ринку, але й простимулювати діяльність економічних агентів.

Ключові слова: банк; бізнес-стратегія; ринок банківських послуг; кластерний аналіз.

DOI: 10.25140/2410-9576-2020-2-1(20)-75-84
UDC 336.71

T. P. Goncharenko, Candidate of Economic Sciences

\section{FEATURES OF BANKS' BUSINESS STRATEGIES IDENTIFICATION IN UKRAINE}

The urgency of the research consists in the necessity to extend the existing methodological framework for defining the business-strategies with the purpose to develop the banking market in Ukraine.

Target setting. It is necessary to form a thorough information base for making effective managerial decisions in the banking management sphere to activate the financial and economic processes in Ukraine.

Actual scientific researches and issues analysis. In the scientific and professional literature, the businessstrategies of banks are studied by such scientists as Gridzhuk D. M., Derkachenko A. V., Khudoliy Yu. S., Zarutska O. P., Panteleeva N. M., Rashkovan V. etc.

Uninvestigated parts of general matters defining. One should mention that nowadays the methodological principles for defining the business-strategies of banks in Ukraine are underdeveloped.

The research objective is to develop a scientific and methodological approach to the identification of business strategies of banks in Ukraine.

The statement of basic materials. Given the general practice of banks, the choice of indicators for the description of their business strategies should form two lines: the sources of banking resources and the financing (lending) direction. Mathematical tools for identifying business strategies of banks include the divisional $k$-means method in terms of many multidimensional research methods and the variance analysis.

Conclusions. When the business strategies of banks are defined in Ukraine, its participants and government regulators will be able to form the most effective market environment in the future. It will intensify not only the development of the banking market but also stimulate the activities of economic agents.

Keywords: bank; business-strategy; banking market; cluster analysis.

Актуальність теми дослідження. Незважаючи на сталі функції банківської системи в економіці, які проявляються в акумуляції тимчасово вільних коштів та подальшого їх перерозподілу, розвиток фінансової системи значно вплинув на види бізнес-стратегії банків. Так, універсальний банкінг, рітейл банкінг та корпоративний банкінг було значно розширено та деталізовано. Крім того, певні банки в Україні обирають комбіновані стратегії власної діяльності. Довготривала, послідовна та виважена поведінка менеджменту банку в межах обраної бізнесстратегії вже довела свою ефективність та обов'язковість реалізації, оскільки тільки за даних умов можливо сформувати повноцінну ресурсну базу для фрінансування необхідних напрямків діяльності. Проте, кожен банк зважаючи на власні фрінансові можливості та людський капітал обирає власну модель поведінки на ринку. Чітка формалізації бізнес-стратегії банків 


\section{ФIHАНСИ. БАНКІВСЬКА СПРАВА}

обумовлено актуальністю розробки на рівні держави та саморегулівні організацій інструментів стимулювання найбільш необхідних для України секторів економки. Таким чином, актуальності набуває продовження наукових досліджень в напрямку фрормування універсальних методичних засад до ідентифікації бізнес-стратегій банків в Україні.

Постановка проблеми. Однак вітчизняні та закордонні науковці тільки починають свій власний пошук в дослідженні процесу ідентифікації бізнес-стратегій банків, які в даний час існують на ринку. В своїй більшості, кожен банк самостійно анонсує базовий вектор власної діяльності. Проте, з метою ефективного розвитку ринку банківських послуг, необхідно мати комплексне уявлення про кластери банків, що формують ту чи іншу бізнес-стратегію. Це дозволить завчасно уникнути системних проблем в банківській сфері та нівелювати ризики для національної економіки. Так, наприклад, перенасичення ринку фінансових послуг банками, які акумулюють власні ресурси за допомогою коштів фрізичних осіб, а спрямовують на фрінансування діяльності юридичних осіб та інших банків може призвести до занепаду малого бізнесу, оскільки він не матиме доступу до кредитних ресурсів.

Аналіз останніх досліджень і публікацій. Сучасні дослідження особливостей визначення та характеристики бізнес-стратегій банків відображені в роботах таких науковців, як Гриджук Д. М., Деркаченко А. В., Худолій Ю. С., Заруцька О. П., Пантєлєєва Н. М., Рашкован В. та Покідін Д.

В свою чергу, базові напрацювання стратегічного управління банківською діяльністю відображені в роботах Гребенюк Н. В. Коваленко В., Колодізєва О. М. Примостки Л., Чмутової І. М. та інших.

Використання математичного інструментарію для вирішення завдань управління банківського сектора та іншими економічними процесами прослідковується в роботах наступних вітчизняних та закордонних дослідників Діденко О., Дордевич С., Хаммерстрем Л., Гібе К., Цверенц Д., Каринцева О., Бенети Р., Юсуф Хосейн Хан, Янн Гарольд Нунамо Нгеді, Пімоненко Т., Радченко О., Палієнко М., Ващенко М., Чернявський I.

Виділення недосліджених частин загальної проблеми. Не применшуючи значення існуючих наукових досліджень банківських бізнес-стратегій актуальності набуває подальший пошук найбільш раціональних методичних засад ідентифікації їх груп у Україні

Постановка завдання. Метою статті $€$ розробка науково-методичного підходу до ідентифікації бізнес-стратегій банків в Україні.

Виклад основного матеріалу. Переходячи до авторської розробки методики ідентифрікації бізнес-стратегій банків зазначимо, що основою її адекватності та можливості подальшого застосування $€$ фрормування універсальної інфрормаційної бази дослідження. Виходячи 3 цього, обрання показників характеристики бізнес-стратегій банків, повинно основуватись на загальних функціях, які характерні банківській системі в цілому та банкам, зокрема. Таким чином, запропоновано виділити два напрямки ідентифікації бізнес-стратегії банків: джерела фрінансування банківської діяльності та напрямки діяльності банків. Для характеристики джерел фрінансування банківської діяльності обрано три показника: кошти банків, кошти суб'єктів господарювання та небанківських фінансових установ, а також кошти фізичних осіб. В свою чергу, для опису напрямків діяльності банків визначено п'ять показників: кошти в інших банках, кредити корпоративному сектору, кредити фізичним особам, придбання цінних паперів та купівля торгових активів. Ще одним показником, який обрано з метою додаткового уточнення бізнес-стратегії банків є загальна вартість власного капіталу, яка дозволяє встановити рівень активності банку на ринку. 3 метою нівелювання розмірів банку, всі вище зазначені дев'ять показників співвідносяться із загальним обсягом активів конкретного банку.

Сформувавши базу даних дослідження в подальшому визначмо методику ідентифікації бізнесстратегії банків. Так, в першу чергу, запропоновано провести кластеризацію усієї сукупності банків на певний рік та встановити найбільш характерні особливості, які притаманні кожній групі досліджуваних фрінансових посередників. Математичний інструментарій реалізації поставленої задачі є ітеративний дивізійний метод k-середніх в розрізі множини багатомірних дослідницьких методів. Його практичну реалізацію доцільно проводити за допомогою програмного комплексу Statistica 8. 


\section{ФIHАНСИ. БАНКІВСЬКА СПРАВА}

Встановивши механізм ідентифікації кластеру, який в нашому випадку є безпосередньою бізнесстратегією банку, актуальності набуває встановлення чисельності даних стратегій в межах кожного періоду дослідження. 3 метою реалізації поставленого завдання запропоновано використати результати дисперсійного аналізу. Даний аналіз дозволяє отримати значення міжгрупових (Between SS) та внутрішньогрупових (Within SS) дисперсійних ознак, які в подальшому перевіряються на адекватність та приймається рішення про прийняття даної чисельності кластерів або продовження дослідження.

3 метою практичної реалізації запропонованих методичних засад ідентифікації бізнес-стратегій банків обрано банківську систему України в 2019 р. Так, сформувавши необхідну вхідну базу дослідження, на основі офріційної статистики НБУ, перейдемо до безпосередньої кластеризації банків України за допомогою програмного комплексу Statistica 8. На основі дисперсійного аналізу визначимо оптимальну кількість кластерів для 2019 р. Отже, значення міжгрупових (Between SS) та внутрішньогрупових (Within SS) дисперсійних ознак в розрізі виділення двох кластерів представлені на (Табл. 1).

Таблиия 1

Дисперсійний аналіз групування банків України на два кластери у 2019 році

\begin{tabular}{|c|c|c|c|c|c|c|}
\hline \multirow{2}{*}{ Змінна } & \multicolumn{6}{|c|}{ Дисперсійний аналіз } \\
\hline & $\begin{array}{l}\text { Міжгрупова } \\
\text { дисперсія }\end{array}$ & $\begin{array}{l}\text { Число } \\
\text { ступенів } \\
\text { вільності }\end{array}$ & $\begin{array}{l}\text { Внутрішньо- } \\
\text { Групова }\end{array}$ & $\begin{array}{l}\text { Число } \\
\text { ступенів } \\
\text { вільності }\end{array}$ & $\begin{array}{l}\text { Критерій } \\
\text { Фішера }\end{array}$ & $\begin{array}{c}\mathrm{p}- \\
\text { критерій }\end{array}$ \\
\hline $\begin{array}{l}\text { Кошти в інших банках (\% від } \\
\text { активів) }\end{array}$ & 37,15 & 1 & 2360,82 & 73 & 1,1489 & 0,287314 \\
\hline $\begin{array}{l}\text { Кредити корпоративному } \\
\text { сектору (\% від активів) }\end{array}$ & 937,64 & 1 & 26781,75 & 73 & 2,5557 & 0,114214 \\
\hline $\begin{array}{l}\text { Кредити фізичним особам (\% від } \\
\text { активів) }\end{array}$ & 75,44 & 1 & 10018,78 & 73 & 0,5497 & 0,460820 \\
\hline $\begin{array}{l}\text { Цінні папери, які обліковуються } \\
\text { за справедливою вартістю через } \\
\text { інший сукупний дохід (\% від } \\
\text { активів) }\end{array}$ & 202,15 & 1 & 9713,10 & 73 & 1,5193 & 0,221681 \\
\hline Торгові активи (\% від активів) & 196,06 & 1 & 25385,05 & 73 & 0,5638 & 0,455145 \\
\hline Кошти банків (\% від активів) & 5,22 & 1 & 2208,84 & 73 & 0,1724 & 0,679217 \\
\hline $\begin{array}{l}\text { Кошти суб'єктів господарювання } \\
\text { та небанківських фрінансових } \\
\text { установ (\% від активів) }\end{array}$ & 1520,92 & 1 & 22354,13 & 73 & 4,9667 & 0,028919 \\
\hline 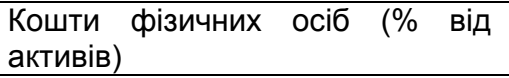 & 827,82 & 1 & 14847,93 & 73 & 4,0700 & 0,047329 \\
\hline $\begin{array}{l}\text { Загальна вартість } \\
\text { капіталу (\% активів) }\end{array}$ & 54950,78 & 1 & 20360,27 & 73 & 197,0213 & 0,000000 \\
\hline
\end{tabular}
даних НБУ [12]

Аналіз результатів групування банків України у 2019 році на два кластери свідчить про неякісно проведену кластеризацію, оскільки значення $p$ в розрізі показників кошти в інших банках, кредити корпоративному сектору, кредити фізичним особам, цінні папери, торгові активи, кошти банків перевищує допустимий для економічних досліджень рівень 0,05. В той же час, саме для даних показників критерій Фішера не є статистично значущим, міжгрупова дисперсія приймає значення від 5 до 937 од., в той час як внутрішньогрупової дисперсії перевищує тисячі. Отже, неадекватність групування банків України на два кластери, призводить до необхідності подальших досліджень.

Аналіз групування банків України на 3 кластери у 2019 році свідчить про покращення якості групування в розрізі кредитів корпоративному сектору та торгових активів і свідчить про низьку якість кластеризації, оскільки лише 5 із 9 показників $€$ статистично значущими. Подальше групування банків від 4 до 7 кластерів (Табл. 2) призводить до підвищення якості дослідження. Лише подальше виокремлення 8 кластерів призводить до зменшення значень міжгрупової, 


\section{ФIНАНСИ. БАНКІВСЬКА СПРАВА}

внутрішноьогрупової дисперсій, критерію Фішера та р-критерію. Даний фракт свідчить про недоцільність подальшого виокремлення кластерів понад 7 груп.

Таблиия 2

Дисперсійний аналіз групування банків України на 7 кластерів у 2019 році

\begin{tabular}{|c|c|c|c|c|c|c|}
\hline \multirow{2}{*}{ Змінна } & \multicolumn{6}{|c|}{ Дисперсійний аналіз } \\
\hline & $\begin{array}{l}\text { Міжгрупов } \\
\text { a } \\
\text { дисперсія }\end{array}$ & $\begin{array}{c}\text { Число } \\
\text { ступенів } \\
\text { вільності } \\
\end{array}$ & $\begin{array}{l}\text { Внутрішньо- } \\
\text { групова }\end{array}$ & $\begin{array}{c}\text { Число } \\
\text { ступенів } \\
\text { вільності }\end{array}$ & $\begin{array}{l}\text { Критерій } \\
\text { Фішера }\end{array}$ & $\begin{array}{c}\text { p- } \\
\text { критерій }\end{array}$ \\
\hline $\begin{array}{l}\text { Кошти в інших банках (\% від } \\
\text { активів) }\end{array}$ & 497,10 & 6 & 1900,87 & 68 & 2,96380 & 0,012481 \\
\hline $\begin{array}{l}\text { Кредити корпоративному } \\
\text { сектору (\% від активів) }\end{array}$ & 21640,04 & 6 & 6079,34 & 68 & 40,34217 & 0,000000 \\
\hline $\begin{array}{l}\text { Кредити фрізичним особам (\% } \\
\text { від активів) }\end{array}$ & 4071,53 & 6 & 6022,69 & 68 & 7,66169 & 0,000003 \\
\hline $\begin{array}{l}\text { Цінні папери, які обліковуються } \\
\text { за справедливою вартістю } \\
\text { через інший сукупний дохід } \\
\text { (\% від активів) }\end{array}$ & 4602,79 & 6 & 5312,47 & 68 & 9,81934 & 0,000000 \\
\hline Торгові активи (\% від активів) & 17234,51 & 6 & 8346,60 & 68 & 23,40166 & 0,000000 \\
\hline Кошти банків (\% від активів) & 971,50 & 6 & 1242,55 & 68 & 8,86105 & 0,000000 \\
\hline $\begin{array}{l}\text { Кошти суб'єктів господарювання } \\
\text { та небанківських фрінансових } \\
\text { установ (\% від активів) }\end{array}$ & 12917,88 & 6 & 10957,16 & 68 & 13,36137 & 0,000000 \\
\hline $\begin{array}{l}\text { Кошти фрізичних осіб (\% від } \\
\text { активів) }\end{array}$ & 9171,53 & 6 & 6504,22 & 68 & 15,98101 & 0,000000 \\
\hline $\begin{array}{lll}\text { Загальна } & \text { вартість } & \text { власного } \\
\text { капіталу (\% активів) } & \\
\end{array}$ & 62425,88 & 6 & 12885,17 & 68 & 54,90757 & 0,000000 \\
\hline
\end{tabular}
даних НБУ [12]

В подальшому відбувається аналіз складу та описової статистики виділених кластерів. Так, переходячи до першого кластеру (Табл. 3), визначимо склад банків України, які його формують. Так, до першого кластеру за методом k-середніх віднесено 9 банків: АТ КБ "ПРИВАТБАНК", АТ "АЛЬФА-БАНК", АТ "ІДея БаНК", АТ "ПРАВЕКС БАНК", АТ "ПІРЕУС БАНК МКБ", АТ "БАНК ФОРВАРД" , АТ "УНІВЕРСАЛ БАНК", АТ "А - БАНК", АТ "Місто Банк". Переходячи до характеристики описових статистик першого кластеру (Табл. 3) в розрізі середнього значення, стандартного відхилення та дисперсії за кожним із 9 обраних показників, зазначимо, що в розрізі даної групи банків України визначальними в розрізі джерел фрінансування банківської діяльності $є$ кошти фізичних осіб $(42,46 \%)$, тоді як напрямки діяльності, не зважаючи на переважання обслуговування фрізичних осіб, розвиваються комплексно.

Таблиця 3

Описові статистики для першого кластеру банків України за 2019 рік

\begin{tabular}{|l|c|c|c|}
\hline \multicolumn{1}{|c|}{ 3мінна } & \multicolumn{3}{|c|}{$\begin{array}{c}\text { Описові статистики для 1 кластеру } \\
\text { Кластер містить 9 банків }\end{array}$} \\
\cline { 2 - 4 } & $\begin{array}{c}\text { Середнє } \\
\text { значення }\end{array}$ & $\begin{array}{c}\text { Cередньоквадратичне } \\
\text { відхилення }\end{array}$ & Дисперсія \\
\hline \multicolumn{1}{|c|}{} & 2 & 3 & 4 \\
\hline Кошти в інших банках (\% від активів) & 5,5600 & 4,87672 & 23,7824 \\
\hline Кредити корпоративному сектору (\% від активів) & 13,0291 & 14,19630 & 201,5349 \\
\hline Кредити фрізичним особам (\% від активів) & 25,8985 & 22,41390 & 502,3829 \\
\hline $\begin{array}{l}\text { Цінні папери, які обліковуються за справедливою } \\
\text { вартістю через інший сукупний дохід (\% від } \\
\text { активів) }\end{array}$ & 7,4331 & 7,82179 & 61,1804 \\
\hline Торгові активи (\% від активів) & 13,6083 & 11,16862 & 124,7380 \\
\hline Кошти банків (\% від активів) & 2,2095 & 4,20926 & 17,7178 \\
\hline
\end{tabular}




\section{ФIHАНСИ. БАНКІВСЬКА СПРАВА}

\begin{tabular}{|l|c|c|c|}
\hline \multicolumn{1}{|c}{1} & \multicolumn{3}{c}{ Продовження таблиці 3 } \\
\hline $\begin{array}{l}\text { Кошти суб'єктів господарювання та небанківських } \\
\text { фінансових установ (\% від активів) }\end{array}$ & 2 & 3 & 4 \\
\hline Кошти фізичних осіб (\% від активів) & 16,8634 & 10,60276 & 112,4186 \\
\hline Загальна вартість власного капіталу (\% активів) & 42,4584 & 9,59519 & 92,0676 \\
\hline
\end{tabular}

Джерело: розраховано автором за допомогою програмного комплексу Statistica 8 на основі офріційних даних НБУ [12]

Переходячи до другого кластеру, зазначимо його склад в розрізі 27 банків, зокрема: AT "Ощадбанк", АБ "УКРГАЗБАНК", АТ "Райффрайзен Банк Аваль", АТ "УКРСИББАНК", АТ "ОТП БАНК", АТ "КРЕДІ АГРІКОЛЬ БАНК", АТ "КРЕДОБАНК", АТ "ПУМБ", Акціонерний банк "Південний", АТ "БАНК КРЕДИТ ДНІПРО", ПАТ "МТБ БАНК", АТ "КБ "ГЛОБУС", АТ "МІБ", ПУАТ "КБ "АКОРДБАНК", АБ "КЛІРИНГОВИЙ ДІМ", АТ "Полтава-банк", АТ "БАНК СІЧ", АТ АКБ "АРКАДА", АТ "АБ "РАДАБАНК", АТ "АКБ "КОНКОРД", АТ "КОМІНВЕСТБАНК", АТ "АЙБОКС БАНК", АТ "УКРБУДІНВЕСТБАНК", АТ "АСВІО БАНК", ПАТ "БАНК "УКРАЇНСЬКИЙ КАПІТАЛ", АТ "СКАЙ БАНК", АТ "ОКСІ БАНК". Найбільш численна група банків в Україні в 2019 р. придержується бізнес-стратегії за якою джерелами діяльності є: кошти юридичних та фрізичних осіб, а кошти спрямовуються на фрінансування торгових активів та діяльності корпоративного сектору (Табл. 4).

Таблиця 4

Описові статистики для другого кластеру банків України за 2019 рік

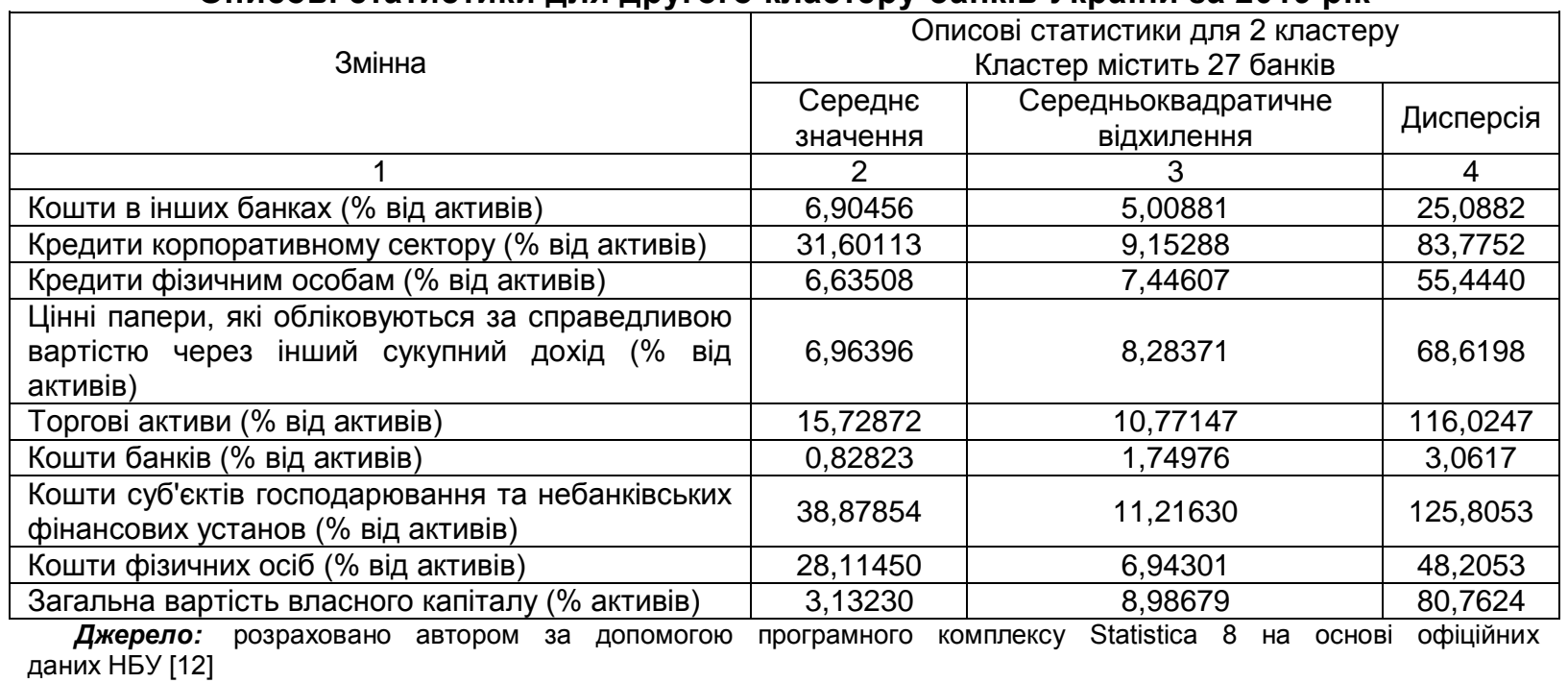

До третього кластеру віднесено 5 банків, зокрема: АТ "СІТІБАНК", АТ "Дойче Банк ДБУ", АТ "СЕБ КОРПОРАТИВНИЙ БАНК", АТ "ПЕРШИЙ ІНВЕСТИЦІЙНИЙ БАНК", АТ "КРИСТАЛБАНК". ДлЯ НИХ характерне визначальне значення коштів суб'єктів господарювання та небанківських фрінансових установ, а також торгові активи, значення яких приймають відповідно 68,76\%, 44,80\% (Табл. 5).

Описові характеристики третього кластеру банків України за 2019 рік

\begin{tabular}{|l|c|c|c|}
\hline \multirow{2}{*}{ 3мінна } & \multicolumn{3}{|c|}{$\begin{array}{c}\text { Описові статистики для 3 кластеру } \\
\text { Кластер містить 5 банків }\end{array}$} \\
\cline { 2 - 4 } & $\begin{array}{c}\text { Середнє } \\
\text { значення }\end{array}$ & $\begin{array}{c}\text { Середньоквадратичн } \\
\text { е відхилення }\end{array}$ & Дисперсія \\
\hline Кошти в інших банках (\% від активів) & 2 & 3 & 4 \\
\hline Кредити корпоративному сектору (\% від активів) & 15,09512 & 11,01023 & 121,2251 \\
\hline Кредити фрізичним особам (\% від активів) & 18,45838 & 2,48637 & 6,1821 \\
\hline
\end{tabular}




\section{ФIHАНСИ. БАНКІВСЬКА СПРАВА}

\begin{tabular}{|c|c|c|c|}
\hline & & \multicolumn{2}{|c|}{ Продовження таблиці 5} \\
\hline 1 & 2 & 3 & 4 \\
\hline $\begin{array}{l}\text { Цінні папери, які обліковуються за справедливою } \\
\text { вартістю через інший сукупний дохід (\% від } \\
\text { активів) }\end{array}$ & 2,35638 & 4,53391 & 20,5564 \\
\hline Торгові активи (\% від активів) & 44,80288 & 10,27171 & 105,5080 \\
\hline Кошти банків (\% від активів) & 3,64115 & 5,14360 & 26,4566 \\
\hline $\begin{array}{l}\text { Кошти суб'єктів господарювання та небанківських } \\
\text { фрінансових установ (\% від активів) }\end{array}$ & 68,76141 & 16,18323 & 261,8970 \\
\hline Кошти фізичних осіб (\% від активів) & 5,80868 & 8,73729 & 76,3403 \\
\hline Загальна вартість власного капіталу (\% активів) & 6,10070 & 6,10995 & 37,3315 \\
\hline
\end{tabular}

Джерело: розраховано автором за допомогою програмного комплексу Statistica 8 на основі офіційних даних НБУ [12]

Склад четвертого кластеру банків України за 2019 рік фрормують ПАТ "РОЗРАХУНКОВИЙ ЦЕНТР", АТ "РВС БАНК", АТ "АЛЬТБАНК", АТ "ЮНЕКС БАНК", ПРАТ "БАНК ФАМІЛЬНИЙ", АТ "БАНК ТРАСТ-КАПІТАЛ", АТ "Український банк реконструкції та розвитку". Визначальними векторами формування ресурсної бази банків четвертого кластеру є кошти юридичних та фрізичних осіб, відповідно по $24 \%$ та $12 \%$, тоді як, майже $62 \%$ отриманих ресурсів йде на фінансування операцій з торговими активами (Табл. 6).

Таблиця 6

Описові характеристики четвертого кластеру банків України за 2019 рік

\begin{tabular}{|c|c|c|c|}
\hline \multirow{2}{*}{ Змінна } & \multicolumn{3}{|c|}{$\begin{array}{c}\text { Описові статистики для } 4 \text { кластеру } \\
\text { Кластер містить } 7 \text { банків }\end{array}$} \\
\hline & $\begin{array}{l}\text { Середнє } \\
\text { значення }\end{array}$ & $\begin{array}{l}\text { Середньоквадратичне } \\
\text { відхилення }\end{array}$ & Дисперсія \\
\hline 1 & 2 & 3 & 4 \\
\hline Кошти в інших банках (\% від активів) & 3,23861 & 3,60566 & 13,0008 \\
\hline Кредити корпоративному сектору (\% від активів) & 9,88255 & 10,06602 & 101,3247 \\
\hline Кредити фрізичним особам (\% від активів) & 2,61785 & 4,44974 & 19,8002 \\
\hline $\begin{array}{l}\text { Цінні папери, які обліковуються за справедливою } \\
\text { вартістю через інший сукупний дохід (\% від } \\
\text { активів) }\end{array}$ & 0,12835 & 0,33959 & 0,1153 \\
\hline Торгові активи (\% від активів) & 61,35099 & 18,68872 & 349,2684 \\
\hline Кошти банків (\% від активів) & 0,65979 & 0,98693 & 0,9740 \\
\hline $\begin{array}{l}\text { Кошти суб'єктів господарювання та небанківських } \\
\text { фрінансових установ (\% від активів) }\end{array}$ & 24,30051 & 15,08443 & 227,5399 \\
\hline Кошти фрізичних осіб (\% від активів) & 12,23086 & 13,74207 & 188,8445 \\
\hline Загальна вартість власного капіталу (\% активів) & 3,00455 & 12,78117 & 163,3583 \\
\hline
\end{tabular}

П'яту групу банків за методом k-середніх складають: АТ "Укрексімбанк", АТ "СБЕРБАНК", АТ "КРЕДИТ ЄВРОПА БАНК", АТ "БАНК АВАНГАРД", АТ "БАНК З/4", АТ "АЛЬПАРІ БАНК". Пріоритетними напрямками характеристики п'ятого кластеру банків України за 2019 рік виступають: в межах напрямків фрінансування - цінні папери (31.18\%), а джерел фінансування кошти суб'єктів господарювання та небанківських фрінансових установ (19,84\%), кредити корпоративному сектору $(18,70 \%)$ та кошти фрізичних осіб (6,5\%) (Табл. 7$)$.

Таблиця 7

Описові характеристики п'ятого кластеру банків України за 2019 рік

\begin{tabular}{|c|c|c|c|}
\hline \multirow{2}{*}{ 3мінна } & \multicolumn{3}{|c|}{$\begin{array}{c}\text { Описові статистики для 5 кластеру } \\
\text { Кластер містить 6 банків }\end{array}$} \\
\cline { 2 - 4 } & $\begin{array}{c}\text { Середнє } \\
\text { значення }\end{array}$ & $\begin{array}{c}\text { Середньоквадратичн } \\
\text { е відхилення }\end{array}$ & Дисперсія \\
\hline Кошти в інших банках (\% від активів) & 2 & 3 & 4 \\
\hline
\end{tabular}




\section{ФIНАНСИ. БАНКІВСЬКА СПРАВА}

\begin{tabular}{|c|c|c|c|}
\hline & & \multicolumn{2}{|c|}{ Продовження таблиці 7} \\
\hline 1 & 2 & 3 & 4 \\
\hline Кредити корпоративному сектору (\% від активів) & 18,70133 & 8,33283 & 69,4361 \\
\hline Кредити фрізичним особам (\% від активів) & 2,91122 & 6,97164 & 48,6038 \\
\hline $\begin{array}{l}\text { Цінні папери, які обліковуються за справедливою } \\
\text { вартістю через інший сукупний дохід (\% від } \\
\text { активів) }\end{array}$ & 31,17701 & 20,27360 & 411,0190 \\
\hline Торгові активи (\% від активів) & 9,96511 & 12,12519 & 147,0203 \\
\hline Кошти банків (\% від активів) & 14,44075 & 11,46091 & 131,3525 \\
\hline $\begin{array}{l}\text { Кошти суб'єктів господарювання та небанківських } \\
\text { фрінансових установ (\% від активів) }\end{array}$ & 19,83865 & 17,66088 & 311,9065 \\
\hline Кошти фрізичних осіб (\% від активів) & 6,49914 & 5,99492 & 35,9391 \\
\hline Загальна вартість власного капіталу (\% активів) & $-3,97049$ & 15,40994 & 237,4661 \\
\hline
\end{tabular}

Шостий кластер формують 19 банків у наступному складі: АТ "ПРОКРЕДИТ БАНК", АТ "ІНГ Банк Україна", АТ "КРЕДИТВЕСТ БАНК", АТ "ТАСКОМБАНК", ПАТ "БАНК ВОСТОК", АТ "МЕГАБАНК", АТ "БАНК ІНВЕСТИЦІЙ ТА ЗАОЩАДЖЕНЬ", АКБ "ІНДУСТРІАЛБАНК", АТ "БАНК АЛЬЯНС", АТ АКБ "ЛЬвів", АТ "БАНК "ГРАНТ", АТ "КІБ", АТ "МОТОР-БАНК", АТ "АП БАНК", АТ "МетаБанК", АТ "КБ "ЗЕМЕЛЬНИЙ КАПІТАЛ", Полікомбанк, АТ "ЄПБ", АТ "БАНК "ПОРТАЛ". Друга за розміром група банків в Україні в 2019 р. характеризується наступним: джерела фінансових ресурсів фрормуються на основі котів фізичних та юридичних осіб, а напрямок діяльності банків спрямовується на кредитування корпоративного сектору (Табл. 8).

Таблиця 8

\section{Описові статистики шостого кластеру банків України за 2019 рік}

\begin{tabular}{|c|c|c|c|}
\hline \multirow{2}{*}{ Змінна } & \multicolumn{3}{|c|}{$\begin{array}{c}\text { Описові статистики для } 6 \text { кластеру } \\
\text { Кластер містить } 19 \text { банків }\end{array}$} \\
\hline & $\begin{array}{l}\text { Середнє } \\
\text { значення }\end{array}$ & $\begin{array}{l}\text { Середньоквадратичне } \\
\text { відхилення }\end{array}$ & Дисперсія \\
\hline Кошти в інших банках (\% від активів) & 6,64920 & 3,87336 & 15,0029 \\
\hline Кредити корпоративному сектору (\% від активів) & 57,19102 & 8,51990 & 72,5886 \\
\hline ПродовжКредити фрізичним особам (\% від активів) & 2,42375 & 2,91699 & 8,5088 \\
\hline $\begin{array}{l}\text { Цінні папери, які обліковуються за справедливою } \\
\text { вартістю через інший сукупний дохід (\% від активів) }\end{array}$ & 2,09495 & 4,25275 & 18,0859 \\
\hline Торгові активи (\% від активів) & 14,36849 & 7,30299 & 53,3336 \\
\hline Кошти банків (\% від активів) & 1,98599 & 3,73375 & 13,9409 \\
\hline $\begin{array}{l}\text { Кошти суб'єктів господарювання та небанківських } \\
\text { фрінансових установ (\% від активів) }\end{array}$ & 30,12560 & 12,40301 & 153,8346 \\
\hline Кошти фрізичних осіб (\% від активів) & 29,02841 & 12,59154 & 158,5468 \\
\hline Загальна вартість власного капіталу (\% активів) & 6,61866 & 5,81774 & 33,8461 \\
\hline
\end{tabular}
даних НБУ [12]

Останнім сьомим кластером виступає найменший за кількістю учасників кластер, склад якого сформовано за рахунок включення ПАТ "Промінвестбанк", АТ "БТА БАНК". Особливістю даної групи банків в Україні $є$ значне від'ємне значення власного капіталу та недоцільність, зважаючи на це, проведення її детальної характеристики (Табл. 9).

Таблиия 9

Описові статистики сьомого кластеру банків України за 2019 рік

\begin{tabular}{|c|c|c|c|}
\hline \multirow{2}{*}{ Змінна } & \multicolumn{3}{|c|}{$\begin{array}{c}\text { Описові статистики для 7 кластеру } \\
\text { Кластер містить 2 банки }\end{array}$} \\
\cline { 2 - 4 } & $\begin{array}{c}\text { Середнє } \\
\text { значення }\end{array}$ & $\begin{array}{c}\text { Середньоквадратичн } \\
\text { е відхилення }\end{array}$ & Дисперсія \\
\hline 1 & 2 & 3 & 4 \\
\hline Кошти в інших банках (\% від активів) & 2,637 & 1,32476 & 1,755 \\
\hline
\end{tabular}




\section{ФIНАНСИ. БАНКІВСЬКА СПРАВА}

\begin{tabular}{|c|c|c|c|}
\hline & & \multicolumn{2}{|c|}{ Продовження таблиці 9} \\
\hline 1 & 2 & 3 & 4 \\
\hline Кредити корпоративному сектору (\% від активів) & 9,982 & 1,56657 & 2,454 \\
\hline Кредити фізичним особам (\% від активів) & 0,651 & 0,92125 & 0,849 \\
\hline $\begin{array}{l}\text { Цінні папери, які обліковуються за справедливою } \\
\text { вартістю через інший сукупний дохід (\% від } \\
\text { активів) }\end{array}$ & 16,964 & 23,98648 & 575,351 \\
\hline Торгові активи (\% від активів) & 10,970 & 10,92279 & 119,307 \\
\hline Кошти банків (\% від активів) & 0,958 & 1,35521 & 1,837 \\
\hline $\begin{array}{l}\text { Кошти суб'єктів господарювання та небанківських } \\
\text { фрінансових установ (\% від активів) }\end{array}$ & 5,019 & 6,74487 & 45,493 \\
\hline Кошти фрізичних осіб (\% від активів) & 4,672 & 6,50979 & 42,377 \\
\hline Загальна вартість власного капіталу (\% активів) & $-167,944$ & 54,58810 & 2979,861 \\
\hline
\end{tabular}

Джерело: розраховано автором за допомогою програмного комплексу Statistica 8 на основі офріційних даних НБУ [12]

Систематизація середніх значень показників характеристики кластерів банків України за 2019 рік дозволяє провести їх графічну інтерпретацію та надати загальну характеристику кожній бізнесстратегії банку (Рис. 1). Таким чином, справедливо зазначити, що для банків першої групи характерна бізнес-стратегія фінансування власної діяльності банків за рахунок фізичних осіб з диверсифрікованим розміщенням коштів; для другої групи банків - бізнес-стратегія фрінансування власної діяльності банків за рахунок корпоративного сектору та вкладів фізичних осіб зі спрямуванням коштів на кредитування корпоративного сектору та операцій з торговими активами; для третьої групи банків - бізнес-стратегія фрінансування власної діяльності банків за рахунок корпоративного сектору зі спрямуванням коштів в операції з торговими активами; для четвертої групи банків - бізнес-стратегія фрінансування власної діяльності банків за рахунок корпоративного сектору та вкладів фізичних осіб зі спрямуванням коштів в операції з торговими активами; для п'ятої групи банків - бізнес-стратегія диверсифрікованого фрінансування зі спрямуванням коштів у цінні папери; для шостої групи банків - бізнес-стратегія фрінансування власної діяльності банків за рахунок корпоративного сектору та фрізичних осіб зі спрямуванням коштів на кредитування корпоративного сектору та операцій з торговими активами.

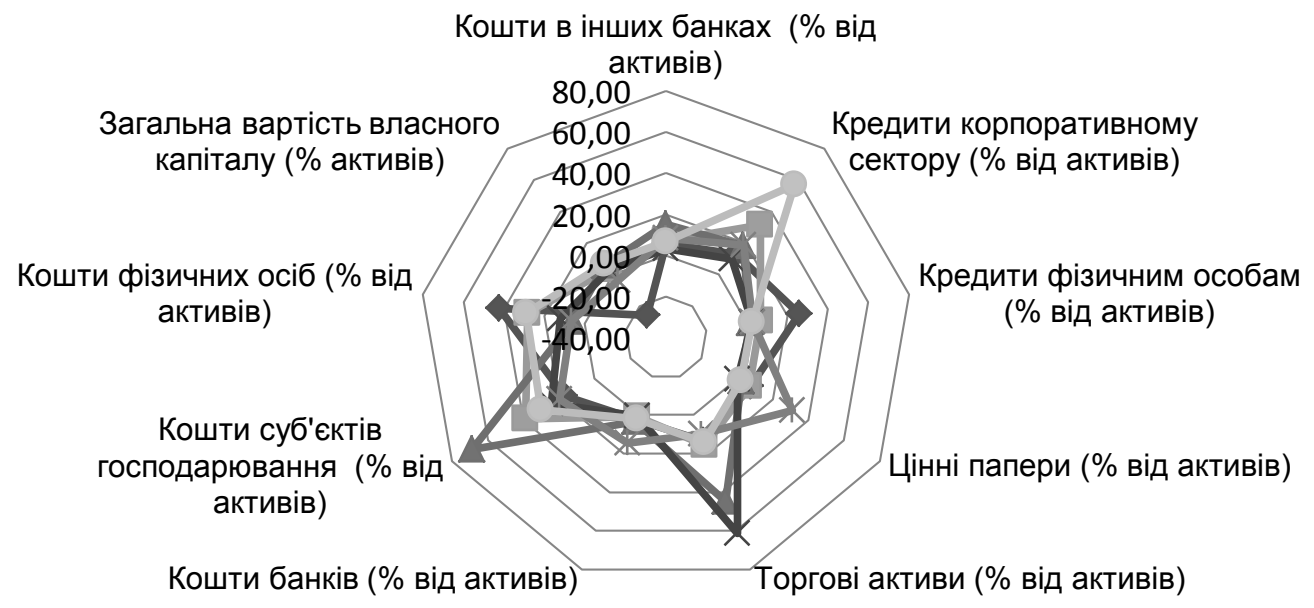

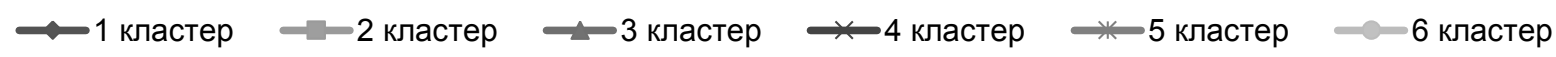

Рис. 1 Візуалізація бізнес-стратегій банків України за 2019 рік

Джерело: побудовано автором за допомогою програмного комплексу Microsoft Excel 


\section{ФIHАНСИ. БАНКІВСЬКА СПРАВА}

Висновки. Таким чином, на основі запропонованої поетапної методики визначення бізнесстратегій банків можливо сформувати інформаційну базу прийняття управлінських рішень щодо розвитку вітчизняного ринку банківських послуг. Отримані результати дозволяють не тільки виявити кількість бізнес-стратегій банків в Україні, але й ідентифікувати чисельність банків, які її складають, а також концентрацію домінуючих напрямків їх діяльності. Подальші наукові дослідження будуть сконцентровані на ретроспективному аналізі бізнес-стратегій в Україні, виявленню їх трансформації з року в рік, ідентифікації чинників, що спричинили дані зміни, а також прогнозуванню майбутньої ситуації на вітчизняному ринку банківських послуг.

\section{Література}

1. Didenko, O., Dordevic, S. (2017). The optimization of banking regulation intensity from the perspective of financial stability in banking sector: an empirical analysis. Financial Markets, Institutions and Risks, 1(1), 43-53. http://doi.org/10.21272/fmir.1(1).43-53.2017.

2. Grebeniuk, N., Jinan Mehdi M. (2017). Features of Foreign Investors Evaluating the Level of Competition in the Banking Market. Financial Markets, Institutions and Risks, 1(3), 99-107. DOI: 10.21272/fmir.1(3).99-107.2017

3. Hammerström, L., Giebe, C., Zwerenz, D. (2019). Influence of Big Data \& Analytics on Corporate Social Responsibility. SocioEconomic Challenges, 3(3), 47-60. http://doi.org/10.21272/sec.3(3).47-60.2019.

4. Karintseva, O., Benetyte, R. (2018). Estimation of Efficiency of State Regulation in Economic Restructuring Based on the Environmental Factor. SocioEconomic Challenges, 2(1), 91-102. DOI: 10.21272/sec.2(1).91102.2018.

5. Md Yusuf Hossein Khan (2018). Strategic Human Resource Practices and its Impact on Performance towards Achieving Organizational Goals. Business Ethics and Leadership, 2(2), 66-73. DOI: 10.21272/bel.2(2).66-73.2018.

6. Nguedie, Y. H. N. (2018). Corruption, Investment and Economic Growth in Developing Countries: A Panel Smooth Transition Regression Approach. SocioEconomic Challenges, 2(1), 63-68. DOI: 10.21272/sec.2(1).63-68.2018.

7. Pimonenko, T., Radchenko, O., Palienko, M. (2017). Efficiency of marketing communications in banks. Business Ethics and Leadership, 1(2), 55-61. Doi: 10.21272/bel.1(2).5561.2017.

8. Vashchenko, M., Cherniavskyi, I. (2017). Gravity model analysis of client-facing choice (in terms of probability evaluation of clients' visits to banks). Business Ethics and Leadership, 1(2), 68-77. Doi: 10.21272/bel.1(2).68-77.2017

9. Zarutska El. (2018). Structural-functional analysis of the Ukraine banking system. Financial Markets, Institutions and Risks, 2(1), 79-96.

10. Гребенюк, Н. В. Концептуальні засади стратегічного управління банком в умовах трансформаційних процесів у банківській системі України. / Н. В. Гребенюк // Науковий вісник НЛТУ України. - 2017. - № 7. - С 65- 69.

11. Гриджук, Д. М. Управлінська структура сучасної бізнес-моделі банку / Д. М. Гриджук // Економіка та держава. - 2018. - №9. - С.44 - 48.

12. Дані фрінансової звітності банків України з сайту Національного банку України [Електронний ресурс]. Режим доступу: http://www.bank.gov.ua.

13. Деркаченко, А. В. Аналіз бізнес-моделей банків України / А. В. Деркаченко, Ю. С. Худолій // Облік і фрінанси. - 2018. - №2 (80). - C.76 - 83 .

14. Заруцька, О. Обґрунтування підходу до масштабного розподілу банків України на основі

\section{References}

1. Didenko, O., Dordevic, S. (2017). The optimization of banking regulation intensity from the perspective of financial stability in banking sector: an empirical analysis. Financial Markets, Institutions and Risks, 1(1), 43-53. http://doi.org/10.21272/fmir.1(1).43-53.2017 [in English].

2. Grebeniuk, N., Jinan, M. M. (2017). Features of Foreign Investors Evaluating the Level of Competition in the Banking Market. Financial Markets, Institutions and Risks, 1(3), 99-107. DOI: 10.21272/fmir.1(3).99-107.2017 [in English].

3. Hammerström, L., Giebe, C., Zwerenz, D. (2019) Influence of Big Data \& Analytics on Corporate Social Responsibility. SocioEconomic Challenges, 3(3), 47-60. http://doi.org/10.21272/sec.3(3).47-60.2019 [in English].

4. Karintseva, O., Benetyte, R. (2018). Estimation of Efficiency of State Regulation in Economic Restructuring Based on the Environmental Factor. SocioEconomic Challenges, 2(1), 91-102. DOI: 10.21272/sec.2(1).91-102.2018 [in English].

5. Khan, M. Y. H. (2018). Strategic Human Resource Practices and its Impact on Performance towards Achieving Organizational Goals. Business Ethics and Leadership, 2(2), 66-73. DOI: 10.21272/bel.2(2).66-73.2018 [in English].

6. Nguedie, Y. H. N. (2018). Corruption, Investment and Economic Growth in Developing Countries: A Panel Smooth Transition Regression Approach. SocioEconomic Challenges, 2(1), 63-68. DOI: 10.21272/sec.2(1).63-68.2018 [in English]

7. Pimonenko, T., Radchenko, O., Palienko, M. (2017). Efficiency of marketing communications in banks. Business Ethics and Leadership, 1(2), 55-61. Doi: 10.21272/bel.1(2).5561.2017 [in English].

8. Vashchenko, M., Cherniavskyi, I. (2017). Gravity model analysis of client-facing choice (in terms of probability evaluation of clients' visits to banks). Business Ethics and Leadership, 1(2), 68-77. Doi: 10.21272/bel.1(2).68-77.2017 [in English].

9. Zarutska, E. (2018). Structural-functional analysis of the Ukraine banking system. Financial Markets, Institutions and Risks, 2(1), 79-96 [in English].

10. Hrebeniuk, N. V. (2017). Kontseptualni zasady stratehichnoho upravlinnia bankom $v$ umovakh transformatsiinykh protsesiv u bankivskii systemi Ukrainy [Some conceptual principles of strategic bank management in the conditionsof transformation processes in the banking system of Ukraine]. Naukovyi visnyk NLTU Ukrainy Scientific Bulletin of UNFU, 7, 65-69 [in Ukrainian]

11. Hrydzhuk, D. M. (2018). Upravlinska struktura suchasnoi biznes-modeli banku [Management structure of the modern bank business model]. Ekonomika ta derzhava Economy and state, 9, 44-48 [in Ukrainian].

12. Dani finansovoi zvitnosti bankiv Ukrainy z saitu Natsionalnoho banku Ukrainy. www.bank.gov.ua. Retrieved from http://www.bank.gov.ua [in Ukrainian].

13. Derkachenko, A. V., Khudolii, Yu. S. (2018). Analiz 


\section{ФІНАНСИ. БАНКІВСЬКА СПРАВА}

структурно-фрункціональних груп / О. Заруцька // Вісник Національного банку України. - 2012. - № 10. - С. 20-24. 15. Коваленко, В. Стратегічне управління фінансовою стійкістю банківської системи: методологія і практика: монографрія / В. Коваленко. - Суми : ДВНЗ «УАБС НБУ», 2010. - 228 с.

16. Колодізєв, О. М. Сценарне моделювання стратегічного управління ринковою вартістю банку / О. М. Колодізєв, Д. Д. Гонтар // Економічний часопис-XXI. 2014. - № 9-10 (2). - С. 19-23.

17. Пантєлєєва, Н. М. Інноваційні бізнес-моделі банків як відповіді на виклики та наслідки фінансової кризи / Н. М. Пантєлєєва // Фінансовий простір. - 2013. - № 3 (11). - C.70 - 76.

18. Примостка, Л. Аналіз банківської діяльності: сучасні концепції, методи та моделі: монографія / Л. Примостка. - К.: КНЕУ, 2002. - 316 с

19. Рашкован, В. Кластерний аналіз бізнес-моделей українських банків: застосування нейронних мереж Кохонена / В. Рашкован, Д. Покідін // Вісник Національного банку України. - 2016. - № 12. - С. 13-40.

20. Чмутова, І. М. Стратегічний вибір банку на різних стадіях його життєвого циклу / І. М. Чмутова // Економічний Часопис XXI. - 2015. - № 5-6. - С. 94-97. biznes-modelei bankiv Ukrainy [Analysis of business models of ukrainian banks]. Oblik $i$ finansy - Accounting and Finance, 2(80), 76-83 [in Ukrainian].

14.Zarutska, O. (2012) Obgruntuvannia pidkhodu do masshtabnoho rozpodilu bankiv Ukrainy na osnovi strukturnofunktsionalnykh hrup [Substantiation of the approach to largescale distribution of Ukrainian banks on the basis of structural and functional groups]. Visnyk Natsionalnoho banku Ukrainy Visnyk of the National Bank of Ukraine, 10, 20-24 [in Ukrainian].

15. Kovalenko, V. (2010) Stratehichne upravlinnia finansovoiu stiikistiu bankivskoi systemy: metodolohiia $i$ praktyka [Strategic management of financial stability of the banking system: methodology and practice]. Sumy: DVNZ "UABS NBU» [in Ukrainian].

16. Kolodiziev, O. M. (2014). Stsenarne modeliuvannia stratehichnoho upravlinnia rynkovoiu vartistiu banku [Scenario modeling of the bank's market value strategic management] Ekonomichnyi chasopys-XXI - Economic Annals-XXI, 9-10(2), 19-23 [in Ukrainian].

17. Pantielieieva, N. M. (2013). Innovatsiini biznes-modeli bankiv yak vidpovidi na vyklyky ta naslidky finansovoi kryzy [Banks innovative business models as a response to the challenges and consequences of the financial crisis]. Finansovyi prostir - Financial Space, 3(11), 70-76 [in Ukrainian].

18. Prymostka, L. (2002). Analiz bankivskoi diialnosti: suchasni kontseptsii, metody ta modeli [Analysis of banking: modern concepts, methods and models]. Kyiv: KNEU [in Ukrainian].

19. Rashkovan, V., Pokidin, D. (2016). Klasternyi analiz biznes-modelei ukrainskykh bankiv: zastosuvannia neironnykh merezh Kokhonena [Cluster analysis of business models of Ukrainian banks: application of Kohonen neural networks]. Visnyk Natsionalnoho banku Ukrainy - Visnyk of the National Bank of Ukraine, 12, 13-40 [in Ukrainian].

20. Chmutova, I. M. (2015). Stratehichnyi vybir banku na riznykh stadiiakh yoho zhyttievoho tsyklu [Commercial bank's strategic choice on the different life cycle stages]. Ekonomichnyi Chasopys XXI - Economic Annals-XXI, 5-6, 94-97 [in Ukrainian].

Надійшла 18.05.2020

Бібліографрічний опис для цитування :

Гончаренко Т. П. Особливості визначення бізнес-стратегій банків в Україні. Науковий вісник Полісся. 2020. № 1 (20)., C. 75-84.

\footnotetext{
Гончаренко

Тетяна Петрівна

кандидат економічних наук, директор Сумського коледжу економіки і торгівлі; https://orcid.org/0000-0001-6298-4517;

E-mail:t_p_goncharenko@ukr.net;

Goncharenko Tetiana Petrivna

Candidate of Economic Sciences, Director of the Sumy College of Economics and Trade; https://orcid.org/0000-0001-6298-4517;

E-mail:t_p_goncharenko@ukr.net;
} 